\title{
CD4+ counts and Oral Lesions in HIV infected/ AIDS patients- an Indian Perspective
}

\author{
Akhilanand Chaurasia* \\ Faculty of Dental Sciences, King George's Medical University, India \\ Submission: January 25, 2017; Published: January 31, 2017 \\ *Corresponding author: Akhilanand Chaurasia, Faculty of Dental Sciences, King George's Medical University, India, \\ Email: chaurasiaakhilanand49@gmail.com
}

\section{Editorial}

HIV infection constitutes a main health problem world ᄀwide. The oral and perioral manifestations are common in HIV infected patients and often influence the debilating general health status, a worse prognosis of the disease as well as a diagnostic factor in the monitoring of the immune status of the patient [1,2]. The vast majority of the HIV infected subjects have presented at least one manifestation in the head and neck area in any state of the disease representing these oral lesions as oral signs of the disease $[3,4]$. In addition the occurrence of these lesions indicate a great susceptibility for opportunistic infections and a great possibility of rapid progression to AIDS [5]. Acquired immunodeficiency syndrome (AIDS) is an infectious disease caused by the HIV and is characterized by profound immunosuppression that leads to opportunistic infections, secondary neoplasm and neurologic manifestations [6]. India is one of those countries where the HIV epidemic is growing rapidly. The National AIDS Control Organization (NACO) estimated that 1.8-2.9 million HIV-positive individuals were living with HIV/ AIDS in India.

Oral manifestations are common in HIV-positive patients and can be used to diagnose the immune status of patients. The fact that oral lesions can be readily detected by a trained clinician in a standardized, objective fashion without any complicated or expensive diagnostic technique has increased their utility [7-9]. Oral lesions might be considered as the initial manifestations of the disease. Oral manifestations of HIV infection are important in the AIDS epidemic and some of them could be used to assess the status of immune suppression and determine the prognosis of the disease. Some oral lesions may even alter patient's quality of life. Early diagnosis and appropriate treatment of oral lesions have great influence on patient's general health and can reduce the mortality rate of the disease [10]. HIV infection remains a significant health care problem. Since Barre Sonoussi and Gallo's initial description of the human immunodeficiency virus type I (HIV1) in 1983 and Clavel et al. first described HIV2 in 1986, these two viruses have been recognized for almost 20 years as the primary cause of the acquired immunodeficiency syndrome (AIDS) [11].

Oral manifestations are among the earliest and most important indicators of HIV infection [12]. At present, three groups of oral manifestations of AIDS are defined based on their intensity and features. Group 1 is composed of seven cardinal lesions (oral candidosis, hairy leukoplakia, Kaposi sarcoma, linear gingival erythema, necrotizing ulcerative gingivitis, necrotizing ulcerative periodontitis, and nonHodgkin lymphoma) that are strongly associated with HIV infection [13]. The second group includes atypical ulcers, salivary glands diseases, viral infection such as cytomegalovírus (CMV), herpes simplex virus (HSV), papillomavirus (HPV), and herpes zoster virus (HZV). On group 3 are lesion rarer than those on groups 1 and 2, such as diffuse osteomyelitis and squamous cell carcinoma [14]. The presence of oral lesions can have a significant impact on health related quality of life. Oral health is strongly associated with physical and mental health, and there are significant increases in oral health needs in people with HIV infection, especially in children, and in adults particularly in relation to periodontal diseases. Thus, physical and mental health measures of HIV patients should incorporate indicators of oral functioning and well-being.

Oral manifestations can suggest, decreased cluster differentiated 4(CD4+) T cell count and increased viral load [15] which might also aid in diagnosis, progression, and prognosis of the disease $[16,17]$. Risk of oral complication increases with immunologic deterioration [18]. Oral examination is therefore useful for early diagnosis which can prolong asymptomatic period, delay disease progression and prevent opportunistic infections with proper education and counseling of patient. The CD4 cell count and viral load have been used lately as the most important laboratory parameter to evaluate the evolution of the disease [19]. Several studies have been focused in the correlation between oral lesions prevalence and the laboratory parameters such as CD4 cell count and viral load in HIV/AIDS patient serum 
evidencing a strong correlation between the oral lesions, lower CD4 cell count and high viral load concluding that these are involved with monitoring and progression of the disease as well as the antiretroviral therapy $[20,21]$.

The ratio of CD4 to CD8 T lymphocytes (CD4-CD8 ratio) is an important diagnostic marker of immune system functioning. The majority of healthy individuals display a CD4-CD8 ratio in the range of 1.5-2.5 to 1 [22] whereas an inverted ratio is characteristic of intense chronic immune responses such as in graft vs host disease and also in several viral illnesses most notably HIV infection [23]. CD4-CD8 ratio predicts the time taken for progression of HIV infection to acquired immune deficiency syndrome (AIDS) and the long-term survival of AIDS patients $[24,25]$. The oral and perioral manifestations are common in HIV infected patients and often influence the debilitating general health status and they can serve as a strong predictor for HIV infection. To date, CD4 cell count, viral load are recognized and widely used as a marker of HIV related disease progression [26]. The stage of infection can be determined by measuring the patient's CD4+ T cell count and the level of HIV in the blood. Acute viremia is associated in virtually all patients with the activation of CD8+ T cells which kill HIV-infected cells and subsequently with antibody production or seroconversion. The CD8+ T cell response is thought to be important in controlling virus levels which peak and then decline.

A good CD8+ T cell response has been linked to slower disease progression and a better prognosis though it does not eliminate the virus. The CD4:CD8 ratio helps determine the risk of disease progression in HIV-infected patients on HAART [27]. Being aware of individual significance of CD4, CD8 cell count and oral lesions in assessing the disease status it was thought worthwhile to correlate whether the presence of specific oral manifestations and the number of different concurrent intraoral lesions among HIV-seropositive patients are associated with the levels of CD4+ cell count, CD8+ cell count and the CD4+/CD8+ ratio and to evaluate whether oral examinations would be an essential component for early recognition of disease. There was higher prevalence of levels of bacterial species in HIV-seronegative than that of HIV-seropositive patients [28]. However a recent animal experimental study shows the presentation of T-cells (including CD4) attenuates the progression of periodontitis [29] .Moreover a study done in HIV-infected subjects found more progression of periodontitis related to low CD4 [30] whereas another study found CD4 has no association with periodontitis progression but high viral load was associated with increased tooth loss [31].

The presence of oral lesion in HIV infected person as well as the presence of wide range of other opportunistic infections is generally accepted as the result of severe immune-suppression caused primarily by destruction of $\mathrm{T}$ helper cells after infection by HIV virus. Indeed it has been shown that the low circulating CD4 cell count is associated with the progression of HIV infection to AIDS and used as a marker for the commencement of the patient therapy. We found a close association between the patient's immune state and the presence of oral candidiasis with an increase in frequency of oral candidiasis as CD4 count decreased. Most of the cases of oral candidiasis were found in low CD4 count $(<200$ cells $/ \mathrm{mm} 3)$ and pseudo membranous candidiasis was the most common variant. The periodontal disease occurred in less severe immune-suppression with its mean CD4 count being 491. The most common variant linear gingival erythema cases were observed in high CD4 count ( $>400$ CD4 cell/ =mm3) [32].

The hairy leukoplakia was not associated with increasing level of immune-suppression because the presence of this oral lesion did not significantly increase as CD4 cell count decreased. These findings were consistent with the findings of other studies $[33,34]$. Recently others investigations have reported that a CD4 cell count less than 200 cells/mm3 and a viral load higher than 10,000 copies $/ \mathrm{ml}$ associated to other factors including tobacco consumption, poor oral hygiene and xerostomia could facilitate the occurrence of oral lesions in these indi-viduals [35]. A low value for $\mathrm{CD} 4+$ cell characterizing the presence of immunesuppression is a predisposing factor for the development of opportunistic infections [36,37]. The fact that the average CD4 percentage was low for children with gingivitis and most of them had serious immunosuppression may also be explained by negligence on the part of those responsible for oral hygiene. More lesions are present in the oral cavity in more immunologically compromised patients. This can make it painful to brush their teeth.The relationship between low CD4 and the presence of conventional gingivitis has also been observed by Howell et al [38]. So it can be concluded that CD4+ cell count plays an important role in manifestations of oral diseases.

\section{References}

1. Ranganathan K, Umadevi M, Saraswathi TR, Kumarasamy N, Solomon S, et al. (2004) Oral lesions and conditions associated with Human Immunodeficiency Virus infection in 1000 South Indian patients. Ann Acad Med Singapore 33(4 Suppl): 37-42.

2. Reichart PA, Khongkhunthian P, Bendick C (2003) Oral Manifestations in HIV infected individuals from Thailand and Cambodia. Med Microbiol Immunol 192(3): 157-160.

3. Schiodt M, Pindborg JJ (1987) AIDS and the oral cavity. Epidemiology and clinical oral manifestations of human immunodeficiency virus infection: a review. Int J Oral Maxillo Surg 16(1): 1-14.

4. Pinheiro A, Marcenes W, Zakrzewska JM, Robinson P (2004) Dental and Oral lesions in HIV infected patients: a study in Brazil. Int Dent J 54(3): 131-137.

5. Greenspan JS (1997) Sentinels and signposts: The epidemiology and significance of the oral manifestations of HIV diseases. Oral Dis 3: S137.

6. EC-Clearinghouse on Oral Problems Related to HIV Infection and WHO Collaborating Centre on Oral Manifestations of the Immunodeficiency Virus (1993) Classification and diagnostic crieteria for oral lesions in HIV infection. J Oral Pathol Med 22(7): 289-291.

7. Hilton JF (1995) Staging the natural history of HIV disease. In: Oral manifestations of HIV infection,Greenspan JS, Greenspan D eds, Quintessence, Carol Stream, p. 42-48. 
8. Glick M, Muzyka BC, Lurie D, Salkin LM (1994) Oral manifestations associated with HIV-related disease as markers for immune suppression and AIDS. Oral Surg Oral Med Oral Pathol 77(4): 344-349.

9. Margiotta V, Campisi G, Mancuso S, Accurso V, Abbadessa V (1999) HIV infection: oral lesions, CD4+ cell count and viral load in an Italian study population. J Oral Pathol Med 28(4): 173-177.

10. Emilio C, Vania L, Vicente F, Iralys B (2009) Oral manifestations of HIV infection in adult patients from the province of Sancti Spiritus, Cuba. J Oral Pathol Med 38(1): 126-131.

11. Ascher MS, Sheppard HW (1988) AIDS as immune system activation: a model for pathogenesis. Clin Exp Immunol 73(2): 165-167.

12. Greenspan D, Komaroff E, Redford M, Phelan JA, Navazesh M, et al. (2000) Oral mucosal lesions and HIV viral load in the Women's Interagency HIV Study (WIHS). J Acquir Immune Defic Syndr 25(1): 44-50.

13. Coogan MM, Greenspan J, Challacombe SJ (2005) Oral lesions in infection with human immunodeficiency virus. Bull World Health Organ 83(9): 700-706.

14. Challacombe S (1991) Revised classification of HIV associated oral lesions. Br Dent J 20(170): 305-306.

15. Ramirez-Amador V, Esquivel-Pedraza L, Sierra-Madero J, AnayaSaavedra G, Gonzalez -Ramirez I, et al. (2003) The changing clinical spectrum of HIV-related oral lesions in 1000 consecutive patients. A twelve year study in a referral centre in Mexico. Medicine 82(1): 39-50.

16. Birnbaum W, Hodgson TA, Reichart PA, Sherson W, Nittayannanta SW, et al. (2002) Prognostic significance of HIV-associated oral lesions and their relation to therapy. Oral Dis 8(2): 110-114.

17. Greenspan JS, Greenspan D (2002) The epidemiology of the oral lesions of HIV infection in the developed world. Oral Dis 8(2): 34-39.

18. Glick M, Muzyka BC, Lurie D, Salkin LM (1994) Oral manifestations associated with HIV-related disease as markers for immune suppression and AIDS. Oral Surg Oral Med Oral Pathol 77(4): 344-349.

19. Mellors JW, Muñoz A, Girodi JV (1997) Plasma viral load and CD4+ lymphocytes as prognostic markers of HIV-1 infection. Ann Intern Med 126(12): 946-954.

20. Aguirre JM, Echebarria MA, Eguia-Del Valle A (2004) Síndrome de inmunodeficiencia adquirida: manifestaciones en la cavidad bucal. Med Oral Patol Oral Cir Bucal 9: 148-157.

21. Margiotta V, Campisi G, Mancuso S, Accurso V, Abbadessa V (1999) HIV infection: oral lesions, CD4+ cellcount and viral load in italian study population. J Oral Pathol Med 28(4): 173-177.

22. Amadori A, Zamarchi R, De Silvestro G, Forza G, Cavatton G, et al. (1995) Genetic control of the CD4/CD8 T-cell ratio in humans. Nat Med 1(12): 1279-1283.

23. Pedersen C, Dickmeiss E, Gaub J, Ryder LP, Platz P, et al. (1990) T-cell subset alterations and lymphocyte responsiveness to mitogens and antigen during severe primary infection with HIV: a case series of seven consecutive HIV seroconverters. Aids 4(6): 523-526.
24. Baillargeon J, Grady J, Borucki MJ (1999) Immunological predictors of HIV-related survival. Int J STD AIDS 10(7): 467-470.

25. Drabick JJ, Williams WJ, Tang DB, Sun W, Chung RC (1992) CD4 lymphocyte decline and survival in human immunodeficiency virus infection. The Military Medical Consortium for Applied Retroviral Research. AIDS Res Hum Retroviruses 8(12): 2039-2047.

26. Bravo IM, Correnti M, Escalona L, Perrone M, Brito A, et al. (2006) Prevalence of oral lesions in HIV patients related to CD 4 cell count and viral load in a Venezuelan population. Med Oral Patol Oral Cir Bucal 11(1): E33-9.

27. Pantaleo G, Demarest JF, Schacker T, Vaccarezza M, Cohen OJ (1997) "The qualitative nature of the primary immune response to HIV infection is a prognosticator of disease progression independent of the initial level of plasma viremia". Proc Natl Acad Sci USA 94(1): 254-258.

28. Gonçalves Lde S, Soares Ferreira SM, Souza CO, Souto R, Colombo AP (2007) Clinical and microbiological profiles of human immunodeficiency virus (HIV)-seropositive Brazilians undergoing highly active antiretroviral therapy and HIV-seronegative Brazilians with chronic periodontitis. J Periodontol 78(1): 87-96.

29. Garlet GP, Cardoso CR, Mariano FS, Claudino M, de Assis GF, et al. (2010) Regulatory $\mathrm{T}$ cells attenuate experimental periodontitis progression in mice. J Clin Periodontol 37(7): 591-600.

30. Choroma_nska M, Waszkiel D (2006) Periodontal status and treatment needs in HIV-infected patients. Adv Med Sci 51: 110-113.

31. Alves M, Mulligan R, Passaro D, Gawell S, Navazesh M, et al. (2006) Longitudinal evaluation of loss of attachment in HIV-infected women compared to HIV uninfected women. J Periodontol 77(5): 773-779.

32. Karagir1A, Pagare S, Krishnamurthy V (2013) Clinical Correlation of Oral Manifestations In HIV Seropositive Patients With CD4+ Cell, CD8+Cell Counts And CD4+/CD8+ Ratio. IOSR Journal of Dental and Medical Sciences (IOSR-JDMS) 7(6): 66-71.

33. Hodgson TA (1997) HIV associated oral lesion: prevalence in Zambia. Oral Disease 3(1): 346-350.

34. Phelan JA, Kein RS (1988) Resolution of hairy leukoplakia during treatment with Azidothymidine. Oral Surg Oral Med Oral Pathol Oral Radio 65(6): 717-720.

35. Aguirre JM, Echebarria MA, Eguia-Del Valle A (2004) Síndrome de inmunodeficiencia adquirida: manifestaciones en la cavidad bucal. Med Oral Patol Oral Cir Bucal 9: 148-57.

36. Moniaci D, Cavallari M, Greco D, Bruatto M, Raiteri R, et al. (1993) Oral lesions in children born to HIV-1 positive women. J Oral Pathol Med 22(1): 8-11.

37. Santos LC, Souza IP, Bundzman ER, Abreu TA (1997) Blood immunologic parameters related to oral candidiasis in HIV+ children. J Dent Res $p$. 76.

38. Howell RB, Jandinsk JJ, Palumbo P, Shey Z, Houpt MI (1996) Oral soft tissue manifestations and CD4 lymphocyte counts in HIV infected children. Pediatr Dent 18(2): 117-120. 

(C) (1) This work is licensed under Creative

\section{Your next submission with Juniper Publishers} will reach you the below assets

- Quality Editorial service

- Swift Peer Review

- Reprints availability

- E-prints Service

- Manuscript Podcast for convenient understanding

- Global attainment for your research

- Manuscript accessibility in different formats ( Pdf, E-pub, Full Text, Audio)

- Unceasing customer service

Track the below URL for one-step submission https://juniperpublishers.com/online-submission.php 